\section{V \\ VERSITA}

\title{
INTERNATIONALIZATION OF THE SERVICE SECTOR \\ - MARKETING APPROACH
}

Mirosława Pluta-Olearnik, Prof.

Department of Marketing

Faculty of Economic Science

University of Economics in Wroclaw

pluta@olearnik.pl

Received 14 June 2011, Accepted 30 July 2011

\begin{abstract}
The main purpose of this article is to indicate the progressive phenomenon of internationalization in the service sector in the context of dynamism of changes concerning economic, technological, legal and social determinants. The first part of this article makes reference to new legal regulations in EU, which fully binding, create special conditions for development of service companies SMB (small and medium businesses) prevailing in the service sector. Further, specific features of services (formula 5 I's) and their marketing typology are discussed. Depending on a sector (a group) of discussing services and their particular characteristic we can point out different stages of entering foreign markets by service companies, strengthening their positions there and various ways of providing customers with their services (from face to face to via technology). In this study practical operations of service firms in foreign markets both B2C and B2B have been specified. The last part shows new challenges for these companies resulting from consumers' new expectations in international markets and also from technological development in this sector.
\end{abstract}

Keywords: services, internationalization, globalization, service firm, consumer services, business services, marketing strategies, international service market, technology.

\section{JEL classification: L84.}




\section{Introduction}

Issues of this article refer to modern tendencies of economies to develop, in which we are watching intensive growth of the service sector contribution and deepening processes of internationalization and globalization supporting these tendencies. The article is aimed at analyzing and assessing possibilities of internationalization growth of different service groups and internationalization of service firms recently, particularly in the context of organization and law forms and also marketing services strategies used in foreign markets. The range of this work concerns consumption services offered in the B2C market and also business services offered in the B2B market. Different sources of information have been used in the article: Internet, books and newspaper publications. To illustrate practical aspects the examples of service companies strategies in foreign markets have been described.

\section{Legal terms and conditions of service operation on EU market}

Service sector in EU is not only the biggest sector of union economies accounting for nearly $70 \%$ of GDP and employment in EU, but it is also the main driving force of growth in the economy and creating new jobs. However, its growth potential is only used to some extend due to obstacles which hinder international trade between EU countries and establishment of new businesses. As a result services still account for $20 \%$ of trans-border trade in EU. The basic legal act in EU about providing services is The Treaty on the Functioning of the European Union, which distinguishes entrepreneurial freedom and freedom of providing services. These rules are expressed in one of the most important EU Acts: The Service Directive (Directive 2006/123/EC of The European Parliament and of The Council of 12 December 2006 on services in the internal market), which applies to services provided by companies operating in any of EU country.

The first legislative initiative concerning acceptance of The Service Directive was in 2004, but possibility of total freedom of providing services turned out to be too controversial. A lot of politicians, especially French and German defied it strongly. The rule concerning the country of origin, which enables service providers to respond only to rules of their national legislation was criticized. Provisions specifying a freedom of registration were rejected. At that time a phrase of Polish plumber was coined who allegedly threatened his French counterpart in the job market. After three years of discussion a modified version of The Directive was accepted. The rule of a origin country was substituted by the freedom of providing services. Some service sectors such as for example health and finances were excluded from The Directive operation ${ }^{1}$. 
The basic provisions within The Service Directive include:

- enabling entrepreneurs to operate due to abolition of legal and administrative barriers,

- simplifying the system of providing trans-border services in different EU countries without an obligation of registering business operations in the form of a department or a partnership,

- enabling entrepreneurs to obtain information and to follow administrative procedures in a specific place in each country,

- gaining an easier access to a wide range of services provided by other entrepreneurs in EU,

- providing consumers with a wide range of a good quality services in all EU.

In accordance with The Service Directive service provider is every natural person who is a citizen of any $27 \mathrm{EU}$ member countries and every legal person who provides services in EU, using entrepreneurial freedom or free flow of services. According to The Directive, the notion of a service provider cannot be limited to trans-border service providing as a part of services flow, but it should also include situations in which a legal entity establishes operations in any EU country in order to expand their business there ${ }^{2}$.

The directive defines the range of services notion widely, including self-employment and paid work. Services seen from this aspect include operations connected with majority of regulated jobs, craftsmen services, services for companies, trade (wholesale and retail turnover of goods and services), tourism services, entertainment services, construction services, installation and maintenance services, IT services, catering and hospitality services, training and educational services, leasing and renting services, services connected with real estate.

Services excluded from application of the directive are as following: all financial services, transport services (air, sea, inland, rail, road), public and private health services, services provided by notaries and bailiffs appointed and empowered by legal acts.

These services apply to general rules of The Community Law, particularly rules of entrepreneurial freedom and freedom of services, which are guaranteed by specific regulations of The Treaty on the Functioning of the European Union. National regulations concerning these services have to be in accordance with the provisions of The Treaty and adjudicated by The Court of Justice of the European Union.

The Service Directive should create easier and more transparent conditions to do businesses. Big corporations will be enabled to make more profits, whereas SMB (small and medium businesses), which have been discouraged from operations in foreign markets until now, can easily enter them. 


\section{Specification of services vs internationalization of service operation}

Many authors have raised the question as to whether services really can be imported or exported. The characteristics of services determine the predominantly "local" structure of service firms. Intangibility leads to service close buyer-supplier interactions. This will complicate the internationalization process in services, but this physical distance can be bridged. For instance, service export between OECD countries accounted for just over $80 \%$ of total OECD export. The largest destination region is the EU with $46 \%$ of service exports ${ }^{3}$. There are three main export and import service sectors: transport, travel, finance and insurance. In the context of internationalization five basic characteristics of services should be described (5I's):

1. Intangibility. Service firms primarily deliver intangibles and service quality and consistent delivery over time are crucial aspects. It is important for international service firm to institutionalize the knowledge gained abroad in terms of procedures, manuals, service processes, IT solutions. Service firms must pay attention to recruiting foreign staff, using local knowledge and developing relationships.

2. Inseparability. It refers to the simultaneous production and consumption of services. This has two main problems for internationalization of services. First is the problem of customer accessibility to the service delivery system - service firms usually have to be in foreign countries because it is quite hard to export service. Second is the problem of difference in culture. But in this context, two kinds of service firms should be distinguished: soft (it is impossible to decouple production and consumption of services, e.g. hairdressing) and hard services firms (it is possible to separate production and consumption, e.g. software).

3. Inconsistency. The servuction process consists of three sets of recourses and each of them may impact differently on the final service quality during and after this process. First are customer recourses and their style of participation the service encounter. Second are contact recourses (service provider and their style of delivering the service). Third are physical recourses. Services firma intending in internationalizing should take cultural differences into account. Approaches found to be effective in one market need not be effective in other market. In practice service providers can meet different service styles, e.g. OSS - the Oriental service style; ASS - the American service style, ESS - the European service style ${ }^{4}$.

4. Inventory. Technology has a tremendous impact on the opportunities to internationalize service firms and also on the choice of their entry mode. It can be possible to avoid the 
necessity of the physical presence during the service encounter - a service firm does not have to have its complete offering on a particular site and it simplifies operations. Technology influences all the 5 I's.

5. Inability to own. It may create a lot of insecurity about the service, especially when perceived risk is high. Trust is the most important factor in creating bonds between the service provider and the customer and makes the possibility to build marketing relationships.

\section{Marketing classification of services and their internationalization}

Talking about issues concerning internationalization of the service sector, it is important to quote such a classification of services which lets us find susceptibility of particular groups (kinds) to processes of their internationalization. Among works in literature about marketing the most extensive are systems of classifications drawn up by Ch. Lovelock, which include the answers to five basic questions:

1. What character an act of providing a service has,

2. What type of relations are between a service company and its customers,

3. What are possibilities of individualization of a service and increasing the staff independence,

4. What character demand and supply of services has,

5. In which way a service is provided ${ }^{5}$.

Lovelock's systems of classifications allow us to build matrixes containing different sets of services which make sectors. Sectors can differ because of:

- The nature of service (mainly the degree of interaction between service provider and customer during the service encounter) and

- The way in which the service is delivered (the degree to which the services are delivered through tangible goods).

The example of a matrix designated by the degree of tangibility of a service (relative involvement of goods) and the degree of interaction between a consumer and a service provider shows Figure 1.

The horizontal axis represents the degree of consumer/producer interaction and the vertical axis represents the relative involvement of goods in a service. For example:

- Services in sector $\mathbf{1}$ are limited in international potential in their present form (e.g. domestic mail delivery), 
- Services in sector 3 are easy to export from the country of origin because they are almost fully embodied in goods (e.g. software or music services),

- Services in sector $\mathbf{4}$ are almost intangible but they have high experience and credence attributes, requiring personal interaction - relatively difficult to store and export (e.g. consulting, advertising, insurances),

- Services in sector 6 require strong interaction with a physical goods and often take place through machines rather than people (e.g. teleshopping, electronic mail). This sector is likely to become globally significant in the future.

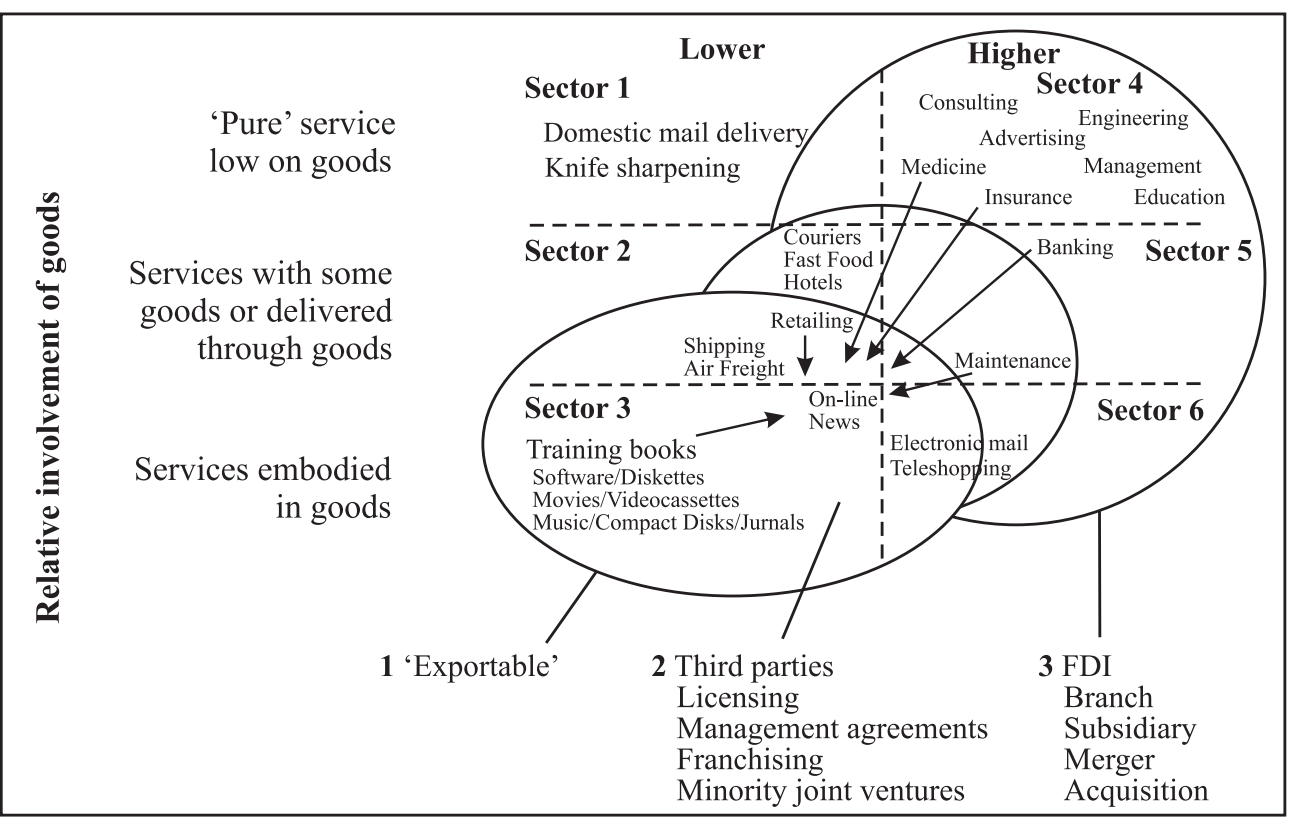

Fig. 1. Grupy usług a sposoby ich internacjonalizacji

Source: Vandermerwe, Chadwick (1989), s. 84.

The set of distinguished sectors is changing if we take into account possible ways of internationalization determined by the range of investment, physical presence and control in a foreign country. According to this approach we get three groups of services (Figure 1):

- Group 1 containing services susceptible to export, where investments, control and steady presence in foreign markets is minimalized (e.g. software, movies, music, journals), 
- Group 2 including services requiring some level of investment, control, and physical presence and the key organizational forms are: licensing, franchising, management agreements, joint venture (e.g. fast food, hotel, couriers, maintenance),

- Group 3 containing more conventional strategies of internationalization of services, because the main resource is staff and the foundation is interaction between personnel and customers. It requires a bigger control of distribution process - direct investments, branches, subsidiaries, mergers and acquisitions are possible there (e.g. consulting, management, banking, insurance, education, advertising, medicine).

A way of providing a service determines then a degree of difficulty and costs of entering a market and connected variants of strategy: export, contract and participation agreements or direct foreign investments.

\section{Internationalization and franchising in the service sector (B2C market)}

Franchising of services in a foreign market means in practice obtaining by a local subject the right to use complete marketing programs, organizational solutions, standards of providing services by a foreign enterprise, often including geographical exclusivity. This form is applied to such service sectors as catering and hospitality and car renting. The best examples of international franchising chains are: Hilton, Sheraton I Holiday Inn; McDonalds I Pizza Hut; Hertz and Avis. The following case study illustrates the strategy of expanding well-known brand of catering chain Subway into Eastern and Central European markets.

\section{Example 1: The Strategy of expanding subway chains in Eastern and Central Europe}

The Subway company belongs to the biggest chains of fast food restaurants in the world. It runs approximately 34,000 restaurants in 95 countries. In Europe itself there are over 3,000 subsidiaries. Plans of the brand expanding for next five years are ambitious - Subway wants to become the biggest chain of fast food in Eastern and Central Europe. All Subway restaurants operate in accordance with franchising rules. On a global scale Subway sold over 2,500 franchising licenses in 2010, half of them outside The USA and Canada. Almost one third of its sold licenses have been used or will be used to open restaurants in unusual places.

Subway franchising chain in Eastern and Central European countries accounts to 250 restaurants and was increased in 2010 by 80 new places - it has been the biggest number of restaurants opened since Subway entered this region of our continent. - The greatest success we have had in Russia, where 50 new restaurants have been opened. In Poland there are 15 places in Bulgaria 6- Martin Princ is counting. 
Polish franchising systems move into foreign markets directly - in 2010 there were 27 systems investing in neighboring countries: Czech Republic, Slovakia, Russia and Lithuania. Foreign companies which come into Polish markets first of all use master license (they have exclusive rights to operate regionally) ${ }^{6}$.

As E. Duliniec emphasizes, international franchising has been developed in service sectors due to high costs of other forms of entering a market (costs of plots or renting a facility). The final success depends on establishing contacts with local suppliers, customers and authorities, knowing the local market and good cooperation with the staff ${ }^{7}$. It is important to notice that dynamic expansion of franchising chains is connected with customers' lifestyle changes, especially international mobility of customers of hotels, restaurants, shops and renting cars.

\section{Internationalization and B2B service market}

It is worth mentioning here that innovative form of legal entities cooperation in the service sector is offshoring, which is a part of services turnover. It was developed in the end of $1990 \mathrm{~s}$, when international corporations started establishing specialized outer enterprises placed in a foreign country. In practice, offshoring is connected with such types of service providing as customer service (e.g. consultancy, cards service, complaints, booking, post selling, administrative, back office), some professional services (legal, accounting, financial, market research), IT services (computing, www servicing, application services), research and development services (research applied, implementation and designing works). Organizational solutions described here have direct influence on marketing strategies of service organizations, particularly in distribution and sale sectors and "de-placing" customer service thanks to new technological solutions.

"Transportation" of services based on ICT (e.g. financial, IT, advertising) is in favor of it. We are observing a phenomenon that is defined as "decomposition of a value chain of service processes" and progressive fragmentation of making them. As a result it favors organizational innovations in so called business market, particularly on an international scale. International marketing of services is a subject to these changes implementing new solutions for strategies in new markets and in new customer segments (e.g. business customers).

It is worth emphasizing that for the future of services "we need to develop competences and organizations need to be prepared to operate under conditions of various possibilities and cultures because expanding globalization forces us to look for success factors on global level 
and it is one of the main challenges for managers' conduct connected with services to a large extend" .

\section{Internationalization and retailing ( $\mathrm{B} 2 \mathrm{C}$ service market)}

In all history of retail internationalization we distinguish several stages. The first stage (in the beginning of 1970s) is a concentric internationalization, which is about entering neighboring markets, similar in terms of geography and culture. The second stage ( the second half of 1970s) is coming into big markets that characterize underdevelopment of modern forms of chain retail. The third stage is about development of formats and specialized chains in foreign markets. Next stage (at the turn of XX/XXI centuries) is about formats of retail designed globally - possible to multiply in an international dimension ${ }^{9}$. The phenomenon of retail internationalization is characterized by dynamics in many aspects: scale, directions, methods of expansion, ways of resources organization. Observing as the example the Polish market, we can indicate three basic methods of internationalization, which are used by foreign investors in retail of fast movement consumer goods (so called FMCG business) ${ }^{10}$ :

- Organic development method - entering a market and expanding by means of investments in own premises, e.g. brands such as Auchan, Lidl, Plus, Aldi, Carrefour.

- Contract development - coming into a market by using agreements' connections (e.g. franchising), for example group E.Leclerc, Intermarche, Carrefour Express and Carrefour 5 minutes.

- Development as a result of mergers and acquisitions - moving into a market and expansion by acquisition, buying a part of a company or a merger with other company, e.g. Jeronimo Martins Distribution (Biedronka), Carrefour.

A great number of foreign entities operating in Poland emphasize attractiveness of that market and liberal rules of accessibility. Foreign retail enterprises invest first of all in development of modern distribution channels (chains of supermarkets and discount shops). Their share in movement of goods FMCG in half of 1990s accounted for several percent, at present it amounts to approximately $40 \%$. The main foreign investors in retail are: Metro Group (Germany), Jeronimo Martins Distribution (Portugal), Tesco (The Great Britain), Carrefour and Auchan (France). 


\section{Conclusions}

Expansion abroad is often driven by needs of international customers (,following customers abroad") - the awareness that international experience in the long run will the enhance the competitive advantage of the firm and chances abroad ${ }^{11}$. More intensified competition in many industries forces companies to look for new markets. With the changes in the nature of service delivery systems, firms may find themselves changing the existing entry mode, or operating in more than one mode. The influence of the changing technology on the internationalization process of service firm is huge. This new mode will require a new thought process, more flexible organizations and managers. The transfer of knowledge will take place face to face or via technology. New managerial formats will be needed to manage a new type of global service operation - geographical separation between front office and back office will become more prevailing. From marketing point of view - international service suppliers are now able to customize services more to local needs and even to individual tastes. Services are now often exportable as a result of ICT, deregulation, asset structure.

\section{Notes}

1 Świadczenie ustug w Unii Europejskiej (2010), p. 10.

2 Ibidem, p. 12.

3 Kasper, Helsdingen, Gabbott (2006), p. 262.

4 Ibidem, p. 271.

5 Payne (1996), s. 51.

6 http://franchising.pl/aktualnosci/raporty/15.03.2011.

7 Duliniec (2009), p. 121.

8 Styś (2009), p. 18.

9 Domański (2010), p. 473.

${ }^{10}$ Borusiak, Małkowska-Borowczyk, Mikołajczyk (2009), pp. 134-135.

${ }^{11}$ Kasper, Helsdingen, Gabbott (2006), p. 297.

\section{References}

Borusiak, B., Małkowska-Borowczyk, M., Mikołajczyk, J. (2009). Internacjonalizacja handlu detalicznego w Polsce - stan obecny i perspektywy, Handel Wewnętrzny, maj. 
Domański, T. (2011). Strategie internacjonalizacji dużych sieci handlowych na polskim rynku. Nowe wyzwania dla marketingu międzynarodowego, in: Marketing międzynarodowy. Uwarunkowania i kierunki rozwoju, J.W. Wiktor, A. Żbikowska (ed), Warszawa: PWE.

Duliniec, E. (2009). Marketing międzynarodowy, Warszawa: PWE.

http://franchising.pl/artykul/5869/subway-podsumowuje-rok/29.01.2011.

Kasper, H., Helsdingen, P., Gabbott, M. (2006). Services Marketing Management - a strategic perspective, Chichester, England: John Willey \& Sons, LTD.

Payne, A. (1996). Marketing ustug, Warszawa: PWE.

Styś, A. (2009). Ustugi: przeszłość, teraźniejszość-przyszłość, w: Przedsiębiorstwo i klientw gospodarce opartej na ustugach, I. Rudawska, M. Soboń (ed.), Warszawa: Difin, p. 18.

Świadczenie usług w Unii Europejskiej. (2010). Warszawa: PARP.

Vandermerwe, S., Chadwick, M. (1989). The internationalization of Services, The service industries Journal, January No. 1. 